\title{
High-level production of poly- $\gamma$-glutamic acid from untreated molasses by Bacillus siamensis IR10
}

\author{
Dexin Wang ${ }^{1,2}$, Hyangmi Kim³ , Sungbeom Lee ${ }^{4,5}$, Dae-Hyuk Kim² and Min-Ho Joe ${ }^{1 *}$ (])
}

\begin{abstract}
Background: Poly- $\gamma$-glutamic acid ( $\gamma-P G A)$ is a promising biopolymer and has been applied in many fields. Bacillus siamensis SB1001 was a newly isolated poly- $\gamma$-glutamic acid producer with sucrose as its optimal carbon source. To improve the utilization of carbon source, and then molasses can be effectively used for $\gamma$-PGA production, ${ }^{60}$ cobalt gamma rays was used to mutate the genes of B. siamensis SB1001.

Results: Bacillus siamensis IR10 was screened for the production of $\gamma$-PGA from untreated molasses. In batch fermentation, $17.86 \pm 0.97 \mathrm{~g} / \mathrm{L} \gamma$-PGA was obtained after $15 \mathrm{~h}$, which is $52.51 \%$ higher than that of its parent strain. Fed-batch fermentation was performed to further improve the yield of $\mathrm{Y}$-PGA with untreated molasses, yielding $41.40 \pm 2.01 \mathrm{~g} / \mathrm{L}$ of $\gamma$-PGA with a productivity of $1.73 \pm 0.08 \mathrm{~g} / \mathrm{L} / \mathrm{h}$. An average $\mathrm{\gamma}$-PGA productivity of $1.85 \mathrm{~g} / \mathrm{L} / \mathrm{h}$ was achieved in the repeated fed-batch fermentation. This is the first report of such a high $\gamma$-PGA productivity. The analysis of the enzyme activities showed that they were affected by the carbon sources, enhanced ICDH and GDH, and decreased ODHC, which are important for $\gamma$-PGA production.
\end{abstract}

Conclusion: These results suggest that untreated molasses can be used for economical and industrial-scale production of $\mathrm{Y}-\mathrm{PGA}$ by $B$. siamensis IR10.

Keywords: Bacillus siamensis IR10, Gamma irradiation, Poly- $\gamma$-glutamic acid, Untreated molasses, Fermentation

\section{Background}

Poly- $\gamma$-glutamic acid ( $\gamma$-PGA) is a high molecular biopolymer composed of glutamic acid repeating units with gamma-amide linkages [1]. The characteristics of $\gamma$-PGA such as excellent water solubility, biodegradability, super absorption, and nontoxicity contribute to a wide range of applications in many fields [2-4]. The high water absorption corresponds with a high viscosity and leads to applications such as a thickener in the food industry [5] and a moisturizer in cosmetics [6]. Moreover, $\gamma$-PGA has great

\footnotetext{
*Correspondence: jomino@kaeri.re.kr

1 Radiation Utilization and Facilities Management Division, Korea Atomic Energy Research Institute, 29 Geumgu-gil, Jeongeup 56212, Republic of Korea

Full list of author information is available at the end of the article
}

applications in other fields, including in drug delivery in medicine [7], biopolymer flocculant adsorption of toxic metal ions used in the sewage treatment industry $[2,8]$, regulation of the soil micro-environment in agriculture, improvement of nitrogen use efficiency, and promotion of plant growth [9].

Most Bacillus strains, including B. subtilis, B. licheniformis, B. amyloliquefaciens, B. methylotrophicus and $B$. megaterium, have been reported to produce $\gamma$-PGA from glucose, glycerol, sucrose, and fructose based media [10-14]. Until now, intensive studies regarding the optimization of the medium composition and fermentation conditions $[10,15]$, metabolic regulation $[16$, $17]$, and genetic engineering methods $[18,19]$ have been done to improve the yield of $\gamma$-PGA. Due to the increasing applications of $\gamma$-PGA, low-cost substrates and high 
productivity are essential for the commercial production of $\gamma$-PGA in addition to increasing the $\gamma$-PGA yield. Inexpensive substrates, such as molasses, a by-product of refining sugarcane, containing high sugar concentrations and several dietary minerals necessary for cell growth and fermentation, already are used for the production of polysaccharides including $\gamma$-PGA [20]. Additionally, rice straw and corncob fibers hydrolysates also have been investigated for the production of $\gamma$-PGA [21, $22]$. Although these low-cost substrates produce a certain amount of $\gamma$-PGA, the productivity is not satisfactory, which is lower than $1.0 \mathrm{~g} / \mathrm{L} / \mathrm{h}$. Thus, when trying to achieve low cost and high productivity, the choice of an efficient $\gamma$-PGA producing strain is essential.

In this study, a Bacillus siamensis SB1001 mutant strain was isolated and named B. siamensis IR10, which can use a variety of sugars including molasses to produce a high amount of $\gamma$-PGA. To explore the mechanism of the mutation, the key enzyme activities at the 2-oxoglutarate branch were determined in B. siamensis SB1001 and IR10 with different carbon source based media. Furthermore, batch, fed-batch, and repeated fed-batch fermentations were performed in a 3-L fermentor for $\gamma$-PGA production from molasses. The results show the highest $\gamma$-PGA productivity compared with previous studies. This strain will serve as a candidate for economical production of $\gamma$-PGA on an industrial-scale.

\section{Methods}

\section{Strains and medium}

Bacillus siamensis SB1001 was isolated from organically cultivated soybeans and maintained in sterile glycerol $(50 \%, \mathrm{w} / \mathrm{v})$ at $-80^{\circ} \mathrm{C}[23]$. The mutant strain $B$. siamensis IR10 was isolated in this study. Basal medium was used for the growth and pre-culture of the strains. It contained $10 \mathrm{~g} / \mathrm{L}$ peptone, $5 \mathrm{~g} / \mathrm{L}$ yeast extract, $10 \mathrm{~g} / \mathrm{L} \mathrm{NaCl}, 20 \mathrm{~g} / \mathrm{L}$ glucose and $20 \mathrm{~g} / \mathrm{L}$ L-glutamic acid.

The fermentation medium consisted of $30 \mathrm{~g} / \mathrm{L}$ L-glutamic acid, $5 \mathrm{~g} / \mathrm{L} \quad \mathrm{NH}_{4} \mathrm{Cl}, 2.4 \mathrm{~g} / \mathrm{L} \quad \mathrm{K}_{2} \mathrm{HPO}_{4}$, $0.5 \mathrm{~g} / \mathrm{L} \quad \mathrm{MgSO}_{4} \cdot 7 \mathrm{H}_{2} \mathrm{O}, 0.04 \mathrm{~g} / \mathrm{L} \quad \mathrm{FeCl}_{3} \cdot 6 \mathrm{H}_{2} \mathrm{O}, 0.15 \mathrm{~g} / \mathrm{L}$ $\mathrm{CaCl}_{2} \cdot 2 \mathrm{H}_{2} \mathrm{O}, 0.104 \mathrm{~g} / \mathrm{L} \mathrm{MnSO}_{4} \cdot \mathrm{H}_{2} \mathrm{O}, 0.5 \mathrm{~g} / \mathrm{L} \mathrm{NaCl}$ and $30 \mathrm{~g} / \mathrm{L}$ carbon source (glucose, sucrose, glycerol, et al.). The effect of the molasses on the production of $\gamma$-PGA was studied by substituting carbon sources with molasses at $80-140 \mathrm{~g} / \mathrm{L}$. The initial $\mathrm{pH}$ was adjusted to $\mathrm{pH} 6.5 \pm 0.1$ with $1 \mathrm{M} \mathrm{NaOH}$.

The molasses was purchased from Byeoli Science Co., Ltd (Jeonju, South Korea), and it contained $28.96 \%$ (w/w) sucrose, $4.58 \%(\mathrm{w} / \mathrm{w})$ glucose, $7.43 \%(\mathrm{w} / \mathrm{w})$ fructose, $14.83 \%(\mathrm{w} / \mathrm{w})$ other carbohydrates, $0.75 \%(\mathrm{w} / \mathrm{w})$ crude protein, $4.40 \%(\mathrm{w} / \mathrm{w})$ salt, $7.35 \%(\mathrm{w} / \mathrm{w})$ ash, $24.16 \%(\mathrm{w} / \mathrm{w})$ water, $8.13 \%(\mathrm{w} / \mathrm{w})$ metal ions such as calcium, potassium, sodium, iron, magnesium, and copper, et al. Before using the molasses, it was diluted two times and centrifuged at $9500 \mathrm{rpm}$ for $20 \mathrm{~min}$ to remove the undissolved substance.

\section{Culture condition and fermentation}

A loopful of cells from the basal medium agar plate was transferred to $50 \mathrm{~mL}$ tubes containing $15 \mathrm{~mL}$ basal medium and incubated for $24 \mathrm{~h}$ at $37^{\circ} \mathrm{C}$ with agitation at $200 \mathrm{rpm}$. The seed culture was adjusted to $\mathrm{OD}_{600}$ to $5.0 \pm 0.1$, and $1 \%(\mathrm{v} / \mathrm{v})$ were transferred to $250 \mathrm{~mL}$ flasks containing $50 \mathrm{~mL}$ of fresh fermentation medium. The flasks were incubated for 24-48 h with shaking at $200 \mathrm{rpm}$ at $37{ }^{\circ} \mathrm{C}$. Each experiment was repeated three times, and data were presented as the mean value.

For bioreactor fermentation, the seed culture $\left(\mathrm{OD}_{600}=5.0 \pm 0.1,1 \%\right)$ was transferred to $500 \mathrm{~mL}$ flasks containing $100 \mathrm{~mL}$ basal medium. After incubation for $12 \mathrm{~h}$ with shaking at $200 \mathrm{rpm}$ at $37{ }^{\circ} \mathrm{C}$, the culture was transferred to a 3-L fermentor (FMT-ST-D03; Bio System Engineering \& Machine Company; Korea) with $0.9 \mathrm{~L}$ fermentation medium and cultured at $37^{\circ} \mathrm{C}$. The fermentor (diameter $14 \mathrm{~cm}$ ) was equipped with two Rushton turbines impellers (diameter $7 \mathrm{~cm}$ ). The bottom impeller was positioned at a height of $3 \mathrm{~cm}$ from the fermentor bottom and the top impeller was located at a distance of $7 \mathrm{~cm}$ from the bottom impeller. $\gamma$-PGA was produced in the batch fermentation with an initial molasses concentration of $100 \mathrm{~g} / \mathrm{L}$ and $30 \mathrm{~g} / \mathrm{L}$ L-glutamic acid. Fed-batch fermentation was conducted with an initial molasses concentration of $100 \mathrm{~g} / \mathrm{L}$ and $60 \mathrm{~g} / \mathrm{L} \mathrm{L}$-glutamic acid. One hundred grams of molasses treated as above, about $150 \mathrm{~mL}$ was added to the bioreactor after sterilization at $121{ }^{\circ} \mathrm{C}$ for $15 \mathrm{~min}$ when the concentration of the total sugar was lower than $5 \mathrm{~g} / \mathrm{L}$. Six repeated fed-batch fermentations were done to investigate the stability of the $\gamma$-PGA production. After a $24 \mathrm{~h}$ fermentation, the broth was removed retaining only $100 \mathrm{~mL}$ and then filled with $900 \mathrm{~mL}$ of fresh fermentation medium containing $100 \mathrm{~g}$ molasses and $60 \mathrm{~g}$ L-glutamic acid. The $\mathrm{pH}$ was automatically controlled at $6.5 \pm 0.1$ by adding $\mathrm{NH}_{4} \mathrm{OH}$ or $1 \mathrm{M}$ $\mathrm{HCl}$ in the fermentors. In the batch culture, the aeration and the agitation speed were maintained at $2 \mathrm{~L} / \mathrm{min}$ and $400 \mathrm{rpm}$. For the fed-batch, after $12 \mathrm{~h}$, the aeration was increased to $3 \mathrm{~L} / \mathrm{min}$, and the agitation speed was adjusted to $600 \mathrm{rpm}$ to maintain the dissolved oxygen above $5 \%$.

\section{Irradiation and isolation of mutant strains}

B. siamensis SB1001 was grown in a $250 \mathrm{~mL}$ flask containing $50 \mathrm{~mL}$ basal medium at $37{ }^{\circ} \mathrm{C}$ with shaking at $200 \mathrm{rpm}$ for $12 \mathrm{~h}$. The bacteria solution was transferred to $15 \mathrm{~mL}$ centrifuge tubes and exposed to dosages of 
1.0, 2.0, and $3.0 \mathrm{kGy}$ in a ${ }^{60}$ cobalt facility (Korea Atomic Energy Research Institute, Jeongup, Republic of Korea) to study the effect of different dosages of ${ }^{60} \mathrm{Co} \gamma$-rays on microbial lethality. Then, the cells were spread onto basal medium agar plates after suitable dilutions and incubated at $37^{\circ} \mathrm{C}$. The survival curve of B. siamensis SB1001 was plotted for the different dosages of gamma irradiation with the colony count method. The radiation dose required to kill above $99.99 \%$ of the microorganisms was chosen as the optimal radiation dose. After irradiation at the optimal dose, the colonies with more wrinkles and higher viscosity were selected in contrast with the wild type colonies.

\section{Analysis of the enzyme activities}

Bacillus siamensis SB1001 and the mutant strain IR10 were grown in fermentation medium with different carbon sources (sucrose, glucose, fructose and molasses) in flasks for $24 \mathrm{~h}$ as described above. The cell extracts were prepared for isocitrate dehydrogenase (ICDH), glutamate dehydrogenase (GDH), $\alpha$-oxoglutarate dehydrogenase complex (ODHC), glutamate $\alpha$-oxoglutarate aminotransferase (GOGAT), and glutamate racemase (GLR) assays. The enzyme activities of ICDH, GDH, ODHC, and GOGAT were determined by measuring the appearance or disappearance of NADH or NADPH at $340 \mathrm{~nm}$ $\left(\varepsilon_{340}=6.22 \mathrm{mM}^{-1} \mathrm{~cm}^{-1}\right)[16,24]$. One unit of enzyme activity was defined as the amount of enzyme catalyzing the formation of $1 \mu \mathrm{mol} \mathrm{NADH}$ or NADPH per min. The GLR enzyme activity was analyzed by the HPLC method [17]. The protein concentration was determined by the Bradford method [25].

\section{Analysis method}

The cell biomass was determined by measuring the absorbance of the broth at $600 \mathrm{~nm}$ using a UV-Vis spectrophotometer (Libra S70PC, Biochrom Ltd., Cambridge, England) [23].

The $\gamma$-PGA concentration was determined by gel permeation chromatography (GPC) system using an Agilent 1100 high-performance liquid chromatography (HPLC) system equipped with a PL aquagel-OH MIXED-H column $(300 \times 7.5 \mathrm{~mm}, 8 \mu \mathrm{m}$; Agilent Technologies, Inc., UK) and refractive index detector (RID). HPLC grade water was used as the mobile phase with the flow rate of $1 \mathrm{~mL} / \mathrm{min}$ and the injection volume of $50 \mu \mathrm{L}$. The amount of $\gamma$-PGA was calculated from the peak area of the GPC measurements with purified $\gamma$-PGA (Bioleaders Corporation, Daejeon, South Korea) as a standard.

Sucrose, glucose and fructose were measured by the HPLC system equipped with an Aminex HPX-87P column $(300 \times 7.8 \mathrm{~mm}$; Bio-Rad, Hercules, CA, USA).
While, L-glutamic acid was measured using a Chire ${ }^{\circledR}$ 3126 (D)-phenicillamine column $(250 \times 4.6 \mathrm{~mm}$; Phenomenex Inc., Torrance, CA, USA) and a UV detector $(254 \mathrm{~nm})$ as described before [23].

\section{Results and discussion \\ Screening for a high $\mathrm{Y}$-PGA producer in a glucose-based medium}

The appropriate dosage rate of ${ }^{60} \mathrm{Co} \gamma$-ray is important to achieve microbial mutation and to determine the microbial lethality. No colonies were found on the agar plates when the dosage was $3.0 \mathrm{kGy}$, suggesting that a high dosage of $\gamma$-ray had a lethal effect on B. siamensis SB1001. In addition, large numbers of colonies formed on the agar plates with a dosage of $1.0 \mathrm{kGy}$. To screen for a glucoseutilizing, high $\gamma$-PGA producing strain, seven mutant colonies whose morphology was mucoid and had more wrinkles than the other colonies were picked from the agar plates. These colonies were exposed to a dosage of $2.0 \mathrm{kGy}$ at the ${ }^{60}$ cobalt facility, and the lethality rates were up to $99.994 \%$. A subsequent comparison of the $\gamma$-PGA production by these mutant strains and wild type was done as described above. Among these strains, all the glucose was exhausted within $24 \mathrm{~h}$. IR10 showed the highest $\gamma$-PGA production $(7.74 \pm 0.35 \mathrm{~g} / \mathrm{L})$, about $180 \%$ higher than that of its parent strain, the growth rate and L-glutamic acid consumption rate were also faster in the glucose-based medium. Besides, IR10 showed the highest conversion rate of $\mathrm{L}$-glutamic acid to $\gamma$-PGA (Table 1 ).

Bacillus siamensis SB1001 is an L-glutamic acid dependent strain. Glucose provides energy but most of the L-glutamic acid was metabolized as a nitrogen source under the impact of glucose [23]. The mutant strain IR10 improved the conversion rate of $\mathrm{L}$-glutamic acid to $\gamma$-PGA, suggesting the activity of enzymes that promote $\gamma$-PGA synthesis might be improved. When bacteria are exposed to gamma rays, a large amount of free radicals and reactive oxygen species are produced, which results in some changes in the nucleic acid base sequence of the bacterial genome [26]. The dose rate of $3.0 \mathrm{kGy}$ might exceed the threshold causing serious damage to the $B$. siamensis SB1001 DNA, which leads to cell death [26]. In this study, gamma radiation was applied to B. siamensis SB1001 to improve its production of $\gamma$-PGA in a glucosebased medium. Previous reports have focused on genetic engineering methods to boost $\gamma$-PGA production, such as NADPH regeneration in B. licheniformis WX-02 [18], cloning of pgsBCA genes in B. amyloliquefaciens LL3 [27], chromosomal integration of the Vitreoscilla hemoglobin gene $(v g b)$ in B. subtilis [28], and construction of energy-conserving sucrose utilization pathways in $B$. amyloliquefaciens [12]. This study is the first report that 
Table 1 Y-PGA production by B. siamensis SB1001 mutant strains

\begin{tabular}{|c|c|c|c|c|c|c|c|c|}
\hline \multirow[t]{2}{*}{ Strains } & \multicolumn{2}{|l|}{$12 \mathrm{~h}$} & \multicolumn{2}{|l|}{$18 \mathrm{~h}$} & \multicolumn{2}{|l|}{$24 \mathrm{~h}$} & \multirow{2}{*}{$\begin{array}{l}\text { Residual } \\
\text { L-glutamic acid } \\
\text { (g/L) }\end{array}$} & \multirow{2}{*}{$\begin{array}{l}\text { Conversion rate } g_{(\mathrm{Y}} \\
\mathrm{PGA}) / g\left({ }_{\text {L-glutamic acid }}\right)\end{array}$} \\
\hline & Biomass (g/L) & $\gamma-P G A(g / L)$ & Biomass (g/L) & $\gamma$-PGA (g/L) & Biomass (g/L) & $\gamma-P G A(g / L)$ & & \\
\hline SB1001 & $2.31 \pm 0.06$ & $1.37 \pm 0.03$ & $3.76 \pm 0.11$ & $2.1 \pm 0.05$ & $4.49 \pm 0.20$ & $2.77 \pm 0.07$ & $16.17 \pm 0.56$ & 0.21 \\
\hline IR5 & $3.93 \pm 0.11$ & $3.77 \pm 0.07$ & $4.02 \pm 0.18$ & $5.30 \pm 0.22$ & $3.78 \pm 0.10$ & $6.62 \pm 0.25$ & $14.41 \pm 0.62$ & 0.42 \\
\hline IR7 & $4.06 \pm 0.18$ & $5.50 \pm 0.23$ & $4.18 \pm 0.18$ & $6.03 \pm 0.24$ & $4.51 \pm 0.18$ & $5.99 \pm 0.24$ & $15.66 \pm 0.55$ & 0.42 \\
\hline IR8 & $4.30 \pm 0.15$ & $0.89 \pm 0.01$ & $4.56 \pm 0.16$ & $1.04 \pm 0.01$ & $5.34 \pm 0.22$ & $1.63 \pm 0.01$ & $18.88 \pm 0.67$ & 0.15 \\
\hline IR9 & $5.13 \pm 0.20$ & $0.79 \pm 0.01$ & $5.19 \pm 0.20$ & $1.60 \pm 0.03$ & $6.08 \pm 0.24$ & $2.18 \pm 0.05$ & $14.23 \pm 0.52$ & 0.14 \\
\hline IR10 & $3.96 \pm 0.12$ & $5.60 \pm 0.23$ & $4.42 \pm 0.18$ & $6.86 \pm 0.31$ & $4.82 \pm 0.21$ & $7.74 \pm 0.35$ & $12.32 \pm 0.48$ & 0.44 \\
\hline IR12 & $3.89 \pm 0.12$ & $1.67 \pm 0.03$ & $5.06 \pm 0.23$ & $1.81 \pm 0.02$ & $6.24 \pm 0.25$ & $1.97 \pm 0.02$ & $13.25 \pm 0.46$ & 0.12 \\
\hline IR14 & $4.28 \pm 0.16$ & $5.51 \pm 0.23$ & $4.42 \pm 0.15$ & $5.69 \pm 0.24$ & $5.08 \pm 0.19$ & $5.79 \pm 0.22$ & $13.66 \pm 0.51$ & 0.35 \\
\hline
\end{tabular}

a gamma radiation mutant strain could promote $\gamma$-PGA production.

\section{Effect of carbon sources on $\gamma$-PGA production by $B$. siamensis SB1001 and IR10}

$\gamma$-PGA production by $B$. siamensis SB1001 and the mutant strain IR10 with different carbon sources was investigated in flasks (Table 2). The results show that, IR10 was better in utilizing the different carbon sources for cell growth and $\gamma$-PGA synthesis compared with SB1001. It could use all the tested carbon sources except for galactose to produce $\gamma$-PGA. A $\gamma$-PGA concentration of $7.74 \pm 0.35 \mathrm{~g} / \mathrm{L}$ and a biomass of $4.82 \pm 0.21 \mathrm{~g} / \mathrm{L}$ were obtained in the glucose-based medium, followed by fructose and sucrose as carbon sources with a $\gamma$-PGA concentration of $7.21 \pm 0.26 \mathrm{~g} / \mathrm{L}$ and $7.14 \pm 0.25 \mathrm{~g} / \mathrm{L}$, respectively. Among the three carbon sources, sucrose was more favorable for cell growth, and the highest biomass of $6.22 \pm 0.28 \mathrm{~g} / \mathrm{L}$ was obtained by using sucrose. Molasses consist of glucose, sucrose and fructose, which might be used as an economic carbon source for the economical production of $\gamma$-PGA by IR10.

Gamma-ray irradiation caused random mutations of B. siamensis, and the increased production of $\gamma$-PGA might indicate mutations in the gene sequences that are expressed in metabolic pathways for different carbon sources. In B. cereus B4081 and B4087, presence of a lactose utilization gene cassette, which encodes 6 -phospho- $\beta$-galactosidase, phosphorylated lactose was hydrolyzed to galactose-6-phosphate and glucose $[29,30]$. B. subtilis contains the genes which encode the proteins necessary for the degradation of lactose and galactose, and these genes are expressed under inducing $\beta$-galactosidase. But the toxic effect of galactose might be occurred due to the accumulation of UDP-galactose [31]. B. siamensis SB1001 can slightly grow on lactose and galactose (Table 2), which might be affected by the toxic of UDP-galactose. However, the mutant strain only utilized galactose for cell growth (Table 2), suggesting that galactose metabolism was through the Leloir pathway in B. siamensis IR10 [32]. Mannose is first phosphorylated

Table 2 Effect of carbon sources on Y-PGA production by B. siamensis SB1001 and mutant strain IR10

\begin{tabular}{|c|c|c|c|c|c|c|c|c|c|c|}
\hline \multirow[t]{3}{*}{ Carbon source } & \multicolumn{4}{|l|}{$12 \mathrm{~h}$} & \multicolumn{4}{|l|}{$24 \mathrm{~h}$} & \multirow{2}{*}{\multicolumn{2}{|c|}{ Biomass ( $P$ value) }} \\
\hline & \multicolumn{2}{|c|}{ Biomass (g/L) } & \multicolumn{2}{|l|}{ V-PGA (g/L) } & \multicolumn{2}{|c|}{ Biomass (g/L) } & \multicolumn{2}{|l|}{ p-PGA (g/L) } & & \\
\hline & SB1001 & IR10 & SB1001 & IR10 & SB1001 & IR10 & SB1001 & IR10 & SB1001 & IR10 \\
\hline Glucose & $2.31 \pm 0.08$ & $3.96 \pm 0.12$ & $1.37 \pm 0.05$ & $5.60 \pm 0.23$ & $4.49 \pm 0.18$ & $4.82 \pm 0.21$ & $2.77 \pm 0.11$ & $7.74 \pm 0.35$ & $1.76 \times 10^{-6}$ & $2.44 \times 10^{-6}$ \\
\hline Fructose & $2.69 \pm 0.07$ & $4.25 \pm 0.13$ & $0.34 \pm 0.01$ & $4.99 \pm 0.18$ & $4.56 \pm 0.17$ & $4.86 \pm 0.21$ & $0.36 \pm 0.02$ & $7.21 \pm 0.26$ & $1.32 \times 10^{-6}$ & $2.36 \times 10^{-6}$ \\
\hline Sucrose & $2.52 \pm 0.08$ & $4.71 \pm 0.13$ & $5.24 \pm 0.23$ & $5.70 \pm 0.21$ & $4.07 \pm 0.14$ & $6.22 \pm 0.28$ & $7.06 \pm 0.26$ & $7.14 \pm 0.25$ & $9.59 \times 10^{-7}$ & $2.77 \times 10^{-6}$ \\
\hline Glycerol & $1.52 \pm 0.05$ & $2.99 \pm 0.09$ & $1.95 \pm 0.06$ & $3.23 \pm 0.12$ & $3.33 \pm 0.14$ & $6.67 \pm 0.26$ & $3.82 \pm 0.15$ & $6.81 \pm 0.22$ & $2.15 \times 10^{-6}$ & $1.56 \times 10^{-6}$ \\
\hline Maltose & $2.58 \pm 0.08$ & $4.08 \pm 0.11$ & $0.33 \pm 0.01$ & $3.32 \pm 0.11$ & $4.36 \pm 0.16$ & $5.97 \pm 0.23$ & $0.55 \pm 0.03$ & $6.98 \pm 0.22$ & $1.24 \times 10^{-6}$ & $1.49 \times 10^{-6}$ \\
\hline Mannose & $0.02 \pm 0.01$ & $4.18 \pm 0.12$ & 0 & $4.09 \pm 0.15$ & $0.02 \pm 0.01$ & $4.80 \pm 0.21$ & 0 & $7.11 \pm 0.24$ & 1 & $2.48 \times 10^{-6}$ \\
\hline Xylose & $1.35 \pm 0.05$ & $2.47 \pm 0.06$ & $0.31 \pm 0.01$ & $1.73 \pm 0.05$ & $4.36 \pm 0.18$ & $5.88 \pm 0.22$ & $0.64 \pm 0.02$ & $6.22 \pm 0.18$ & $1.98 \times 10^{-6}$ & $1.33 \times 10^{-6}$ \\
\hline Lactose & $0.42 \pm 0.02$ & $4.46 \pm 0.14$ & 0 & $3.79 \pm 0.14$ & $1.38 \pm 0.03$ & $5.79 \pm 0.20$ & 0 & $7.09 \pm 0.25$ & $1.95 \times 10^{-7}$ & $9.65 \times 10^{-7}$ \\
\hline Galactose & $0.18 \pm 0.01$ & $1.27 \pm 0.13$ & 0 & 0 & $0.51 \pm 0.02$ & $3.09 \pm 0.15$ & 0 & $0.72 \pm 0.03$ & $2.88 \times 10^{-6}$ & $3.81 \times 10^{-6}$ \\
\hline
\end{tabular}

Initial biomass $(0 \mathrm{~h}) 0.02 \mathrm{~g} / \mathrm{L}$; Statistical analysis was performed for the biomass at $0 \mathrm{~h}$ and $24 \mathrm{~h}$. $P$-values $<0.05$ showed the significant differences 
to mannose-6-phosphate by hexokinase and then converted to fructose-6-phosphate by mannose-6-phosphate isomerase [33]. B. siamensis SB1001 cannot use mannose (Table 2) because the relative enzymes might not be expressed. Thus, mutations may occur in the genes encoding the enzymes for the lactose, mannose and galactose metabolism pathways.

It was reported that glucose can affect the $\gamma$-PGA synthetic enzyme system and catabolite control protein $\mathrm{A}$ (CcpA) [34]. CcpA possesses several functions, such as control of lactose transport, $\beta$-galactosidase activity, and glycolysis [35], CcpA represses the TCA cycle and activates the EMP pathway when glucose is present in the medium [36]. Additionally, previous research found that a low concentration of glucose was better for the production of $\gamma$-PGA by B. siamensis SB1001 [23]. Unfortunately, the effect of other carbon sources on $\gamma$-PGA synthesis has not been studied. Fructose, maltose, and xylose could support the growth of B. siamensis SB1001, but they did not promote $\gamma$-PGA synthesis (Table 2). Thus, another mutation in the gene sequence might control the $\gamma$-PGA synthetic pathway and its relative proteins. In the future, the whole transcriptomes of the wild and mutant strains need to be compared using mRNA sequencing.

\section{Effect of the molasses concentration on $\gamma$-PGA production by mutant strain IR10}

Based on the metabolism of the different carbon sources, different concentrations of molasses were chosen for the $\gamma$-PGA production. The results in Fig. 1 imply that the molasses was a suitable carbon source for $\gamma$-PGA synthesis. $\gamma$-PGA concentration and the biomass were increased by increasing the concentration of the molasses from $80-120 \mathrm{~g} / \mathrm{L}$. The maximum $\gamma$-PGA production of $14.44 \pm 0.55 \mathrm{~g} / \mathrm{L}$ with the productivity of $0.41 \pm 0.02 \mathrm{~g} / \mathrm{L} / \mathrm{h}$ and biomass of $8.02 \pm 0.38 \mathrm{~g} / \mathrm{L}$ were obtained at $120 \mathrm{~g} / \mathrm{L}$ molasses at $36 \mathrm{~h}$. However, the $120 \mathrm{~g} / \mathrm{L}$ molasses concentration initially showed inhibition during the first $12 \mathrm{~h}$; moreover, a molasses concentration of $140 \mathrm{~g} / \mathrm{L}$ showed significant inhibition of cell growth and $\gamma$-PGA synthesis. A biomass of $7.15 \pm 0.36 \mathrm{~g} / \mathrm{L}$ was obtained at $100 \mathrm{~g} / \mathrm{L}$ molasses, and the $\gamma$-PGA concentration was $13.71 \pm 0.51 \mathrm{~g} / \mathrm{L}$ with the productivity of $0.46 \pm 0.02 \mathrm{~g} / \mathrm{L} / \mathrm{h}$ after $30 \mathrm{~h}$; the lower concentration may be caused by the lower sugar concentration in the molasses.

Untreated molasses normally contain some unknown essential nutrients, which could stimulate cell growth [20]. It also contains some metal ions and ash, which could be toxic for cells [37]. When B. siamensis IR10 was cultured in medium with over $120 \mathrm{~g} / \mathrm{L}$ molasses, the number of metal ions and ash exceeded the tolerance limit of strain; thus, $\gamma$-PGA synthesis and cell growth were inhibited. A similar phenomenon has been reported for S. albulus PD-1, in which the optimum concentration of the untreated cane molasses was $40 \mathrm{~g} / \mathrm{L}$. The biomass, poly ( $\varepsilon$-L-lysine), and poly (L-diaminopropionic acid) concentrations all decreased when the initial molasses concentration was over $40 \mathrm{~g} / \mathrm{L}$ [37]. In this study, $100 \mathrm{~g} / \mathrm{L}$ of initial molasses in the medium was selected for the economic production of $\gamma$-PGA by IR10.

\section{Batch fermentation of untreated molasses for $\mathrm{\gamma}$-PGA production}

To confirm the feasibility of untreated molasses as a sole carbon source for $\gamma$-PGA production by the mutant strain, batch fermentation was performed in $3 \mathrm{~L}$ fermentors, and the wild type strain was used as the control. Compared with the wild type strain, the mutant strain showed a higher biomass $(12.78 \pm 0.43$ vs $10.26 \pm 0.35 \mathrm{~g} / \mathrm{L}$ ) (Fig. 2a), higher $\gamma$-PGA yield $(17.86 \pm 0.97$ vs $11.71 \pm 0.58 \mathrm{~g} / \mathrm{L})$, higher $\gamma$-PGA productivity $(1.19 \pm 0.06$ vs $0.78 \pm 0.04 \mathrm{~g} / \mathrm{L} / \mathrm{h})$ and lower residual L-glutamic acid $(5.80 \pm 0.29$ vs $16.05 \pm 0.78 \mathrm{~g} / \mathrm{L})$ after $24 \mathrm{~h}$ (Fig. 2b), suggesting that the mutant strain IR10 had more advantages in producing $\gamma$-PGA. Unfortunately, the mutant strain showed a lower conversion rate of L-glutamic acid to $\gamma$-PGA $\left(0.91 \mathrm{~g}_{\gamma \text {-PGA }} / \mathrm{g}_{\mathrm{L} \text {-glutamic acid }}\right)$ than its parent strain $\left(1.16 \mathrm{~g}_{\gamma-\mathrm{PGA}} / \mathrm{g}_{\mathrm{L} \text {-glutamic acid }}\right)$.

The time course of utilization of sucrose, glucose, and fructose in the untreated molasses is shown in Fig. 2c. Sucrose was rapidly hydrolyzed into glucose and fructose before $8 \mathrm{~h}$, and there was no significant difference in the consumption rates by the two strains. The levels of glucose and fructose first increased in the medium, indicating that $B$. siamensis possesses sucrose-utilization systems. There were obvious differences in the utilization of glucose and fructose between the IR10 and SB1001. The mutant strain could metabolize glucose and fructose much faster. Furthermore, the glucose consumption rate was higher than that of fructose. After the glucose was exhausted at $10 \mathrm{~h}$, the fructose consumption increased, which might be caused by the effects of catabolic repression [38]. Interestingly, all the carbon sources exhausted after $15 \mathrm{~h}$; the two strains continued to consume $\mathrm{L}$-glutamic acid, but the production of $\gamma$-PGA did not increase. The phenomenon was consistent with the previous description that L-glutamic acid was metabolized as a nitrogen source to maintain the growth of cells [39]. Sucrose was the best carbon source for B. siamensis SB1001 and L-glutamic acid could be converted from sucrose through the tricarboxylic acid cycle [23]. But in B. siamensis IR10, the conversion rate of $\mathrm{L}$-glutamic acid to $\gamma$-PGA was lower than $1.0 \mathrm{~g}_{\gamma \text {-PGA }} / \mathrm{g}_{\mathrm{L} \text {-glutamic acid }}$, might be caused by the high biomass consumed more sugars and more L-glutamic acid consumed as a nitrogen source. 


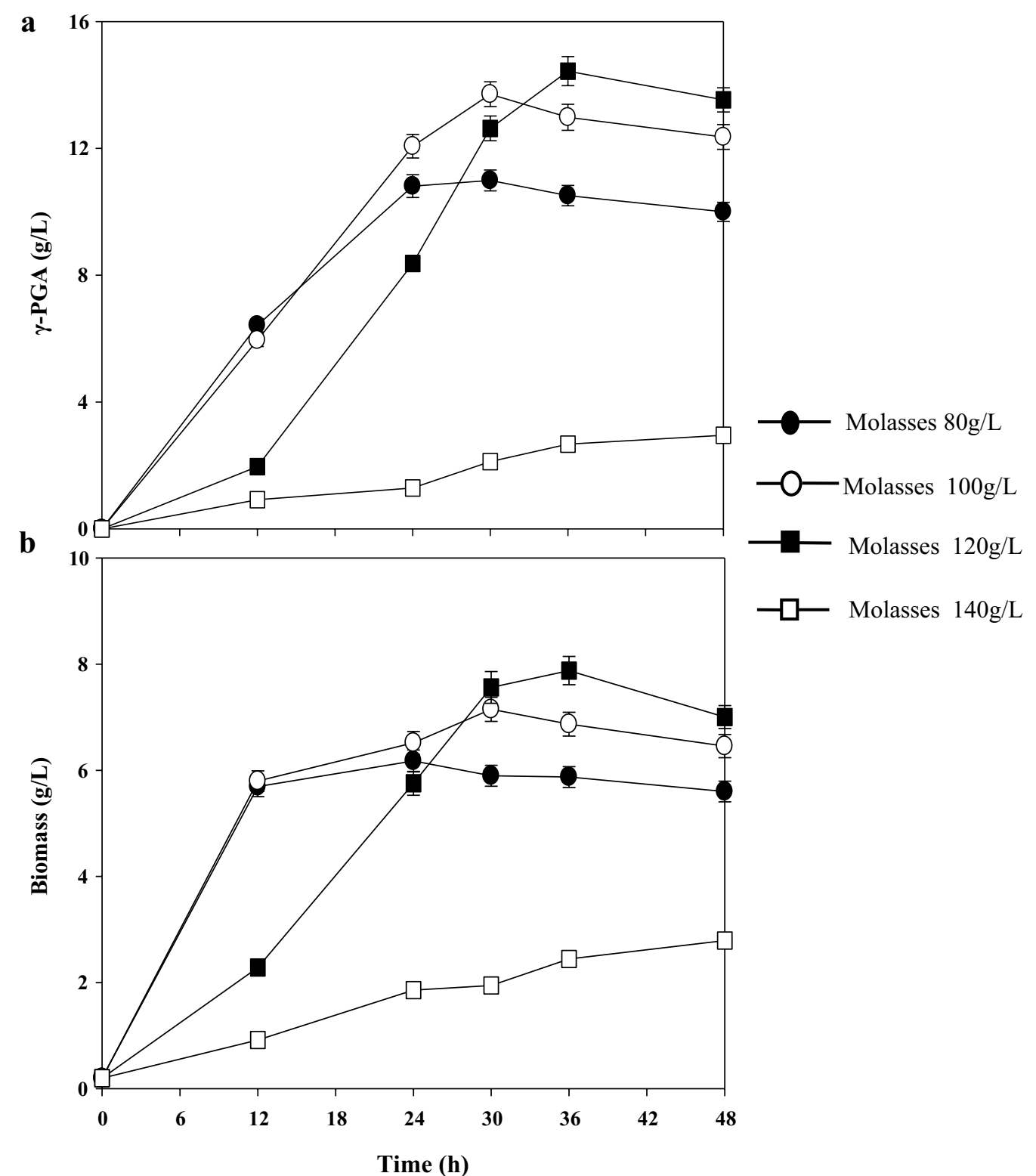

Fig. 1 Effect of the molasses concentration for $\gamma$-PGA production by B. siamensis IR10

Fed-batch fermentation for $\mathrm{Y}$-PGA production by $B$. siamensis IR10

The batch fermentation results showed that untreated molasses is a potential low-cost carbon source for $\gamma$-PGA production by $B$. siamensis IR10. To test the feasibility of an industrial application, the fed-batch fermentation of untreated molasses was performed in a fermentor and the dissolved oxygen level was remained above $5 \%$ (Fig. 3a). As shown in Fig. 3b, when the initial concentration of L-glutamic acid was $60 \mathrm{~g} / \mathrm{L}, 41.40 \pm 2.01 \mathrm{~g} / \mathrm{L}$ of $\gamma$-PGA were obtained with a $\gamma$-PGA productivity of $1.73 \pm 0.08 \mathrm{~g} / \mathrm{L} / \mathrm{h}$, and the highest biomass was $14.69 \pm 0.71 \mathrm{~g} / \mathrm{L}$ during $24 \mathrm{~h}$ of cultivation. Furthermore, the conversion rate of L-glutamic acid to $\gamma$-PGA up to $101.38 \%$ ( $\mathrm{g}_{\gamma-\mathrm{PGA}} / \mathrm{g}_{\text {L-glutamic acid }}$ ), suggesting the possible transformation of abundant carbon sources to endogenous glutamic acid.

Some attempts have been made to improve the $\gamma$-PGA production with molasses including hydrolysis of the molasses and immobilized cell fermentation [20, 40]. Until now, the highest $\gamma$-PGA concentration was $52.1 \mathrm{~g} / \mathrm{L}$ with a productivity of $0.54 \mathrm{~g} / \mathrm{L} / \mathrm{h}$ with molasses 

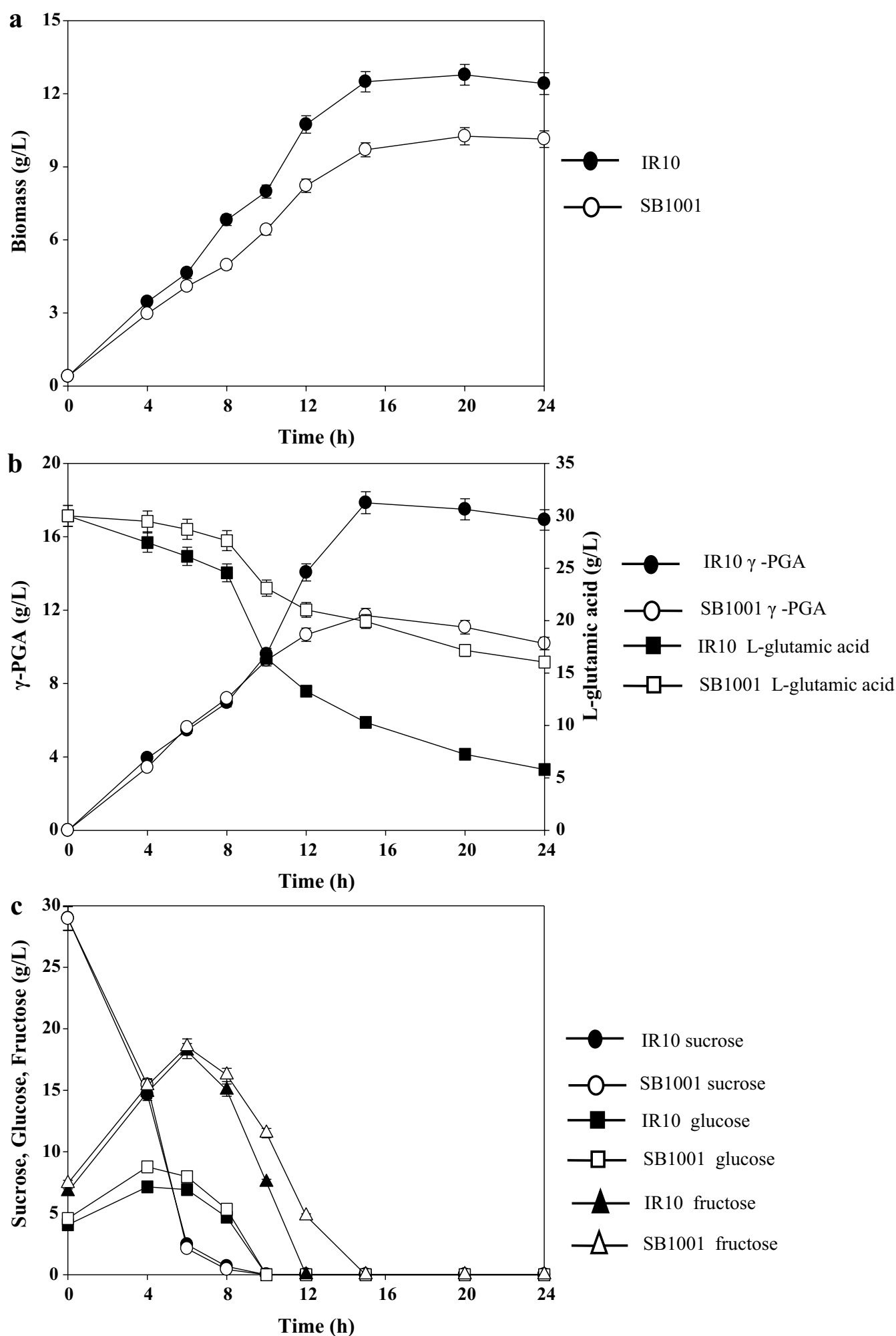

Fig. 2 Comparison between B. siamensis SB1001 and mutant strain IR10 for $\mathrm{Y}$-PGA production using molasses in the fermentor 

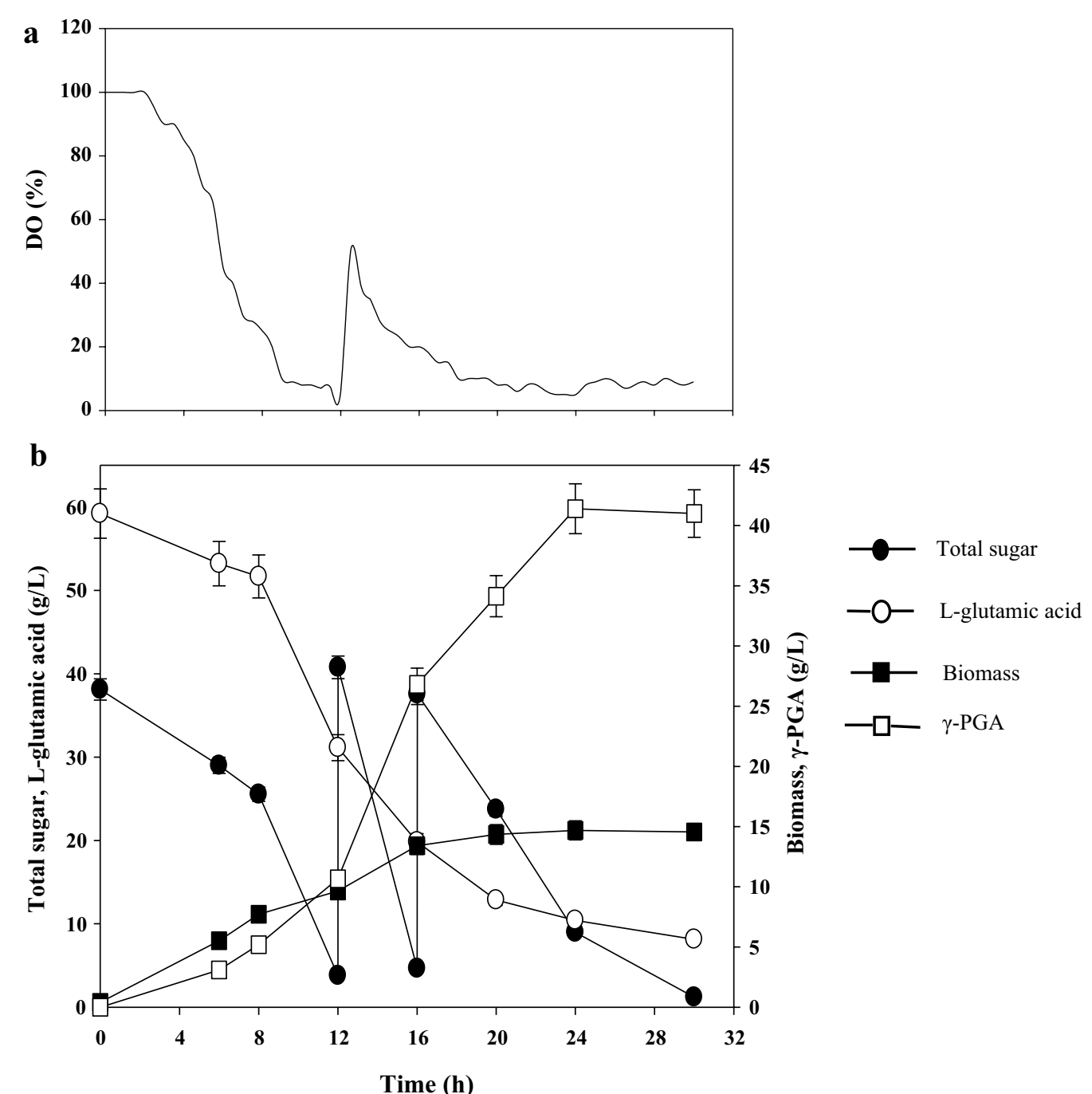

Fig. 3 Fed-batch fermentation of $\gamma$-PGA using untreated molasses in the fermentor by B. siamensis IR10

as the carbon source [20]. The $\gamma$-PGA productivity in this study is the highest compared to previous reports. The concentration of $\gamma$-PGA did not increase after $24 \mathrm{~h}$, which perhaps was caused by the decreased activity of the enzyme controlling the synthesis of $\gamma$-PGA. Oxygen plays an important role in $\gamma$-PGA synthesis; the production of $\gamma$-PGA increases the medium viscosity and thus reduces the mass transport. During fed-batch fermentation, the dissolved oxygen was maintained above 5\% (Fig. 3a), meanwhile, we found that further increase agitation speed and aeration did not increase dissolved oxygen and did not increase the $\gamma$-PGA concentration (data not show). Previous research reported that dissolved oxygen level remained $5 \%$ is the minimum acceptable value and remained high dissolved oxygen $(\geq 20 \%)$ was beneficial to improve $\gamma$-PGA production [41]. But in a bioreactor, increasing the stirring rate and aeration might not be enough to enhance dissolved oxygen, one possible approach was added the oxygen carriers [42]. Another reason might be that a high concentration of molasses contains more harmful substances that exceed the tolerance ability of the strain. Further optimization of the fermentation process to enhance the $\gamma$-PGA yield should be carried out. Anyway, molasses can be efficiently utilized in $\gamma$-PGA production by B. siamensis IR10, which may contribute to the commercial-scale production of $\gamma$-PGA by industry byproducts.

\section{Repeated fed-batch fermentation for $\mathrm{Y}$-PGA production by $B$. siamensis IR 10}

To investigate the long-term stability and maximize the $\gamma$-PGA production, repeated fed-batch fermentations 
were done in this study. This approach has been widely used to improve the productivity of $\gamma$-PGA because it reduces the delay period of the strains [40,43]. Based on the fed-batch results, we performed repeated fed-batch fermentations of B. siamensis IR10 for six cycles each $24 \mathrm{~h}$ long (Fig. 4). As shown in Table 3, the cell growth and $\gamma$-PGA productivity increased as the batch number increased.

In the first cycle, the biomass reached $14.88 \pm 0.49 \mathrm{~g} / \mathrm{L}$ and then increased each cycle and finally stayed constant at $17.08 \pm 0.57 \mathrm{~g} / \mathrm{L}$ in the last two cycles. From first to the last cycle, the $\gamma$-PGA concentration increased from $40.06 \pm 1.33 \mathrm{~g} / \mathrm{L}$ to $45.42 \pm 1.36 \mathrm{~g} / \mathrm{L}$ and stayed constant at about $45 \mathrm{~g} / \mathrm{L}$. During the repeated fed-batch fermentation, the high $\gamma$-PGA productivity (1.67$2.02 \mathrm{~g} / \mathrm{L} / \mathrm{h}$ ) was successfully maintained with an average of $1.85 \mathrm{~g} / \mathrm{L} / \mathrm{h}$. The results suggest that $\gamma$-PGA production in the repeated fed-batch was highly stable and showed prominent advantages. Several strategies have been made to improve $\gamma$-PGA production and productivity shown in Table 4. B. subtilis NX-2 had the highest yield of $\gamma$-PGA $(74.2 \mathrm{~g} / \mathrm{L})$ with a productivity of $1.24 \mathrm{~g} / \mathrm{L} / \mathrm{h}$ [43]. However, their $\gamma$-PGA productivity was much lower than the value of $1.85 \mathrm{~g} / \mathrm{L} / \mathrm{h}$ observed in the present study. Although the repeated fed-batch in this study does not provide the highest $\gamma$-PGA concentration, the $\gamma$-PGA production rate is the highest and more economical with molasses as the carbon source.

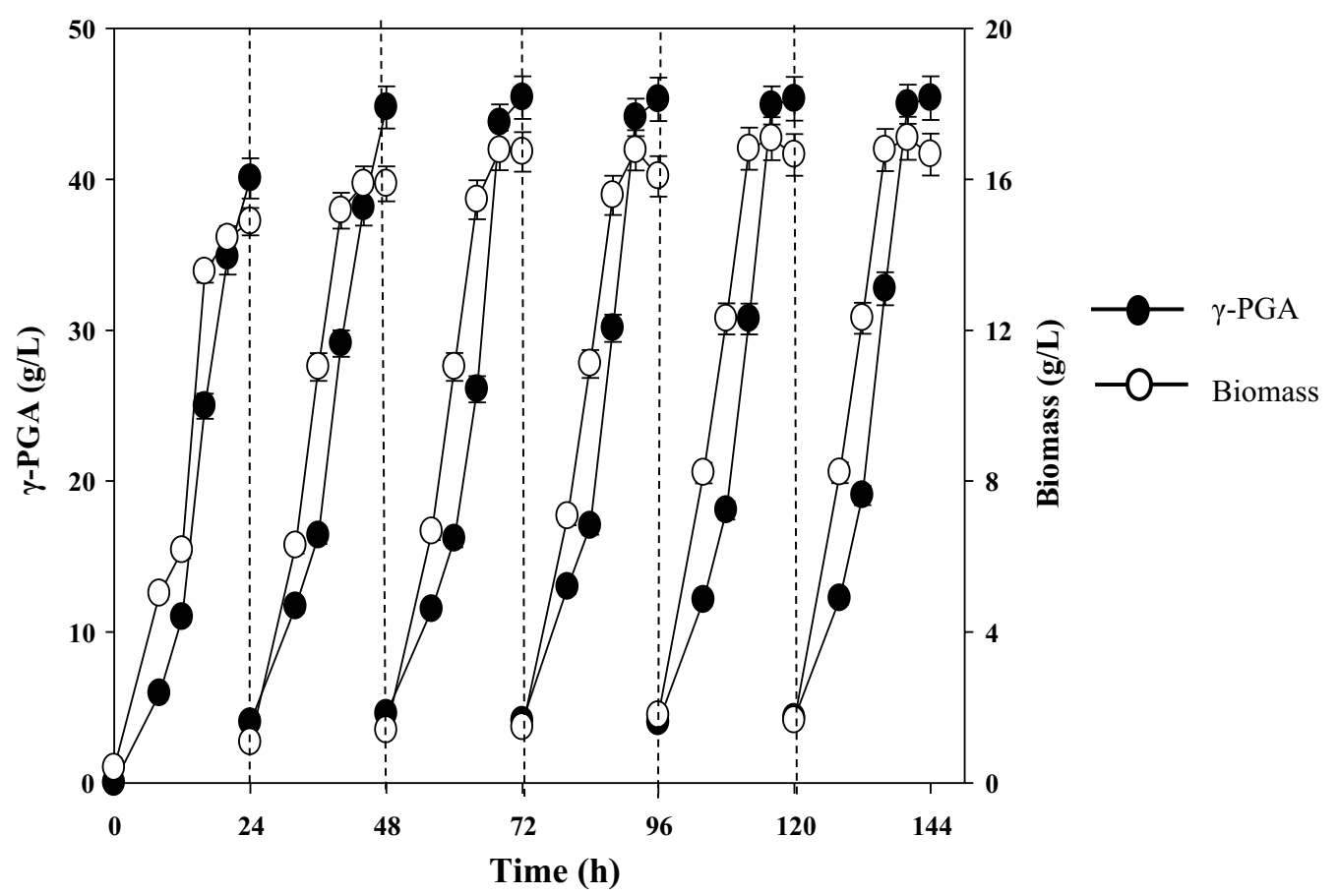

Fig. 4 Repeated fed-batch fermentation of $\mathrm{Y}$-PGA using untreated molasses in the fermentor by B. siamensis IR10

Table 3 Comparison of parameters of each cycle for $\mathrm{Y}$-PGA production by $B$. siamensis IR10 in repeated fed-batch fermentation

\begin{tabular}{lllllll}
\hline Cycle number & $\mathbf{1}$ & $\mathbf{2}$ & $\mathbf{3}$ & $\mathbf{4}$ & $\mathbf{5}$ & $\mathbf{6}$ \\
\hline Time $(\mathrm{h})$ & 24 & 24 & 24 & 20 & 20 & 20 \\
Biomass (g/L) & $14.88 \pm 0.49$ & $15.88 \pm 0.52$ & $16.73 \pm 0.55$ & $16.77 \pm 0.56$ & $17.08 \pm 0.57$ & $17.09 \pm 0.56$ \\
Y-PGA concentration (g/L) & $40.06 \pm 1.33$ & $44.77 \pm 1.39$ & $45.42 \pm 1.41$ & $44.10 \pm 1.23$ & $44.90 \pm 1.26$ & $44.98 \pm 1.26$ \\
Y-PGA productivity (g/L/h) & $1.67 \pm 0.05$ & $1.70 \pm 0.06$ & $1.71 \pm 0.06$ & $1.98 \pm 0.06$ & $2.02 \pm 0.06$ & $2.02 \pm 0.06$ \\
\hline
\end{tabular}

The productivity was calculated according to the produced $\mathrm{Y}$-PGA production as follows

Cycle 1: $40.06 \div 24=1.67 ;$ Cycle 2: $(44.77-4.00) \div 24=1.70$; Cycle 3: $(45.42-4.40) \div 24=1.71$; Cycle $4:(44.10-4.54) \div 20=1.98$

Cycle $5:(44.90-4.53) \div 20=2.02$; Cycle $6:(44.98-4.53) \div 20=2.02$ 
Table 4 Comparison of $\mathrm{\gamma}$-PGA production and productivity in the fermentor

\begin{tabular}{|c|c|c|c|c|c|}
\hline Strain & Key nutrients & Fermentation process & Production (g/L) & Productivity (g/L/h) & References \\
\hline B. licheniformis NCIM 2324 & $\begin{array}{l}\text { L-Glutamic acid, citric acid, } \\
\text { sugarcane juice, } \mathrm{NH}_{4} \mathrm{Cl}\end{array}$ & $\begin{array}{l}\text { Membrane-integrated hybrid } \\
\text { reactor system }(30 \mathrm{~L}) \text {, continu- } \\
\text { ous feed fermentation }\end{array}$ & 36.5 & 0.91 & [49] \\
\hline B. licheniformis P-104 & $\begin{array}{l}\text { Sodium glutamate, glucose, } \\
\text { sodium citrate, }\left(\mathrm{NH}_{4}\right)_{2} \mathrm{SO}_{4}\end{array}$ & Fed-batch fermentation (7 L) & 41.6 & 1.07 & {$[50]$} \\
\hline B. subtilis NX-2 & Glutamate, glucose, $\left(\mathrm{NH}_{4}\right)_{2} \mathrm{SO}_{4}$ & $\begin{array}{l}\text { Aerobic plant fibrous-bed } \\
\text { bioreactor }(7.5 \mathrm{~L}) \text {, repeated } \\
\text { fed-batch fermentation }\end{array}$ & 71.21 & 1.246 & {$[40]$} \\
\hline B. subtilis BL53 & $\begin{array}{l}\text { Glutamic acid, citric acid, glyc- } \\
\text { erol, } \mathrm{NH}_{4} \mathrm{Cl}\end{array}$ & $\begin{array}{l}\text { Bioreactor }(5 \mathrm{~L}) \text { with oxygen car- } \\
\text { rier, batch fermentation }\end{array}$ & 23.5 & 0.98 & [42] \\
\hline B. subtilis NX-2 & Glutamate, glucose, $\left(\mathrm{NH}_{4}\right)_{2} \mathrm{SO}_{4}$ & $\begin{array}{l}\text { Moving bed biofilm reactor } \\
(7.5 \mathrm{~L}) \text {, repeated fed-batch } \\
\text { fermentation }\end{array}$ & 74.2 & 1.24 & [43] \\
\hline B. siamensis IR10 & L-Glutamic acid, molasses, $\mathrm{NH}_{4} \mathrm{Cl}$ & $\begin{array}{l}\text { Fed-batch and repeated fed- } \\
\text { batch fermentation }(3 \mathrm{~L})\end{array}$ & $41.4-45.42$ & $1.67-2.02$ & This work \\
\hline
\end{tabular}

Enzyme activity analysis around the 2-oxoglutarate branch in B. siamensis SB1001 and IR10

B. siamensis IR10 showed good advantages in utilizing glucose, fructose, and molasses for the production of $\gamma$-PGA. Although different carbon sources have different metabolic pathways, the pathway to $\gamma$-PGA synthesis is unique, which is around the 2-oxoglutarate branch. Thus, we analyzed the effect of different carbon sources on the activities of enzymes around the 2-oxoglutarate branch.

As shown in Fig. 5, the enzyme activities of $\mathrm{ICDH}$, ODHC, GDH, GOGAT, and GLR were different in $B$. siamensis SB1001 and B. siamensis IR10 when cultured in different carbon sources. There was no significant difference in the tested enzyme activities in a sucrosebased medium (Fig. 5a); thus, it did not affect the production of $\gamma$-PGA between the wild type and mutant strain (Table 2). The activities of ICDH increased from $4.73 \times 10^{-3}$ to $6.27 \times 10^{-3}, 4.12 \times 10^{-3}$ to $6.69 \times 10^{-3}$, and $5.57 \times 10^{-3}$ to $6.58 \times 10^{-3} \mathrm{U} / \mathrm{mg}$ when cultured in a glucose-, fructose-, and molasses-based medium, respectively. Meanwhile, the activities of GDH increased from $7.15 \times 10^{-3}$ to $22.78 \times 10^{-3}, 8.64 \times 10^{-3}$ to $16.64 \times 10^{-3}$, and $13.71 \times 10^{-3}$ to $16.08 \times 10^{-3} \mathrm{U} / \mathrm{mg}$ (Fig. $5 \mathrm{~b}-\mathrm{d}$ ), respectively. In addition, the activity of ODHC in $B$. siamensis IR10 decreased by more than 3- and 1.8-fold compared to the wild type strain when glucose and fructose were the carbon sources, respectively. The activities of GOGAT and GLR increased in B. siamensis IR10 when only cultured in the fructose-based medium.

For B. siamensis IR10, ICDH and GDH had a higher activity compared with the wild type strain when cultured in the glucose- and fructose-based medium. This result shows that ICDH and GDH had positive regulation for $\gamma$-PGA production in $B$. siamensis SB1001, which is consistent with B. subtilis GXA-28
[16]. According to a previous report, GOGAT showed a greater contribution than GDH to the conversion of $\alpha$-oxoglutarate to glutamate [44]. In the current study, the contributions of the two enzymes were not compared. Both the wild type and mutant strains had a low activity of ODHC when producing a high yield of $\gamma$-PGA, suggesting ODHC has the most important role in controlling the flux distribution at the 2-oxoglutarate branch in B. siamensis SB1001. Previous research found that ODHC was the greatest impact factor on glutamate production, and glutamate production was markedly increased by the attenuation of the ODHC activity [45]. Interestingly, the carbon sources can affect the enzyme activities, the regulation could take place at the level of the CcpA response to the different carbon sources and mixtures. CcpA is a key factor in the regulation of carbon metabolism, carbon sources can affect the complex of CcpA represses many genes and operons for regulation TCA cycle and control of nitrogen source metabolism [46]. Also, CcpA plays an important role in the regulation of metabolism for $\gamma$-PGA synthesis, GOGAT and GDH activities were regulated by CcpA in the presence of different carbon sources in Bacillus sp. [47]. Another reason perhaps caused by the redox reaction involved with $\mathrm{NADP}^{+}$and NADPH, which shows an imbalance in the central carbon metabolism, which could affect the TCA cycle and amino acids metabolism [48].

\section{Conclusion}

In this study, a mutant strain B. siamensis IR10 was screened successfully using the ${ }^{60} \mathrm{Co} \gamma$-ray mutation method. A high $\gamma$-PGA concentration and productivity were obtained with a molasses-based medium in 


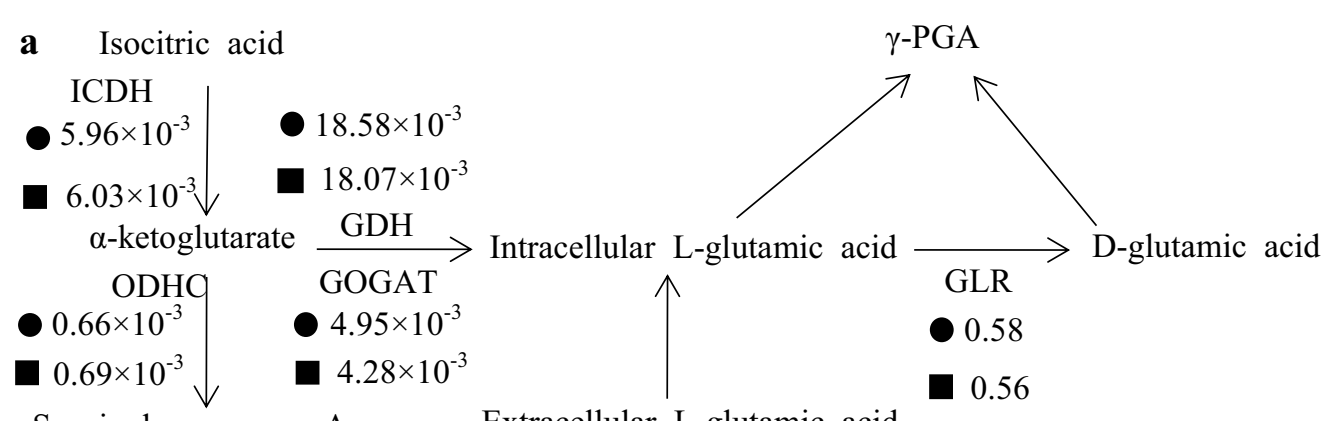

Succinyl coenzyme A Extracellular L-glutamic acid

b Isocitric acid

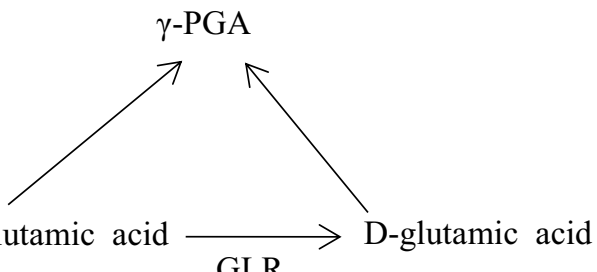

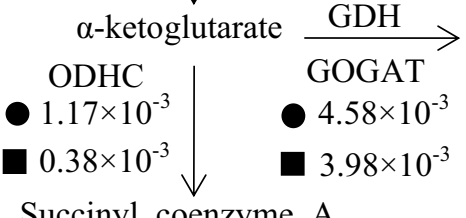

- $7.15 \times 10^{-3}$

$\mathrm{ICDH}$

$4.73 \times 10^{-3}$

- $22.78 \times 10^{-3}$

$6.27 \times 10^{-3} \downarrow$

GDH

Succinyl coenzyme A

Extracellular L-glutamic acid

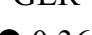

- 0.36

0.45

c Isocitric acid
ICDH

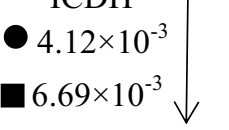
- $8.64 \times 10^{-3}$
- $16.64 \times 10^{-3}$
$\alpha$-ketoglutar
ODHC
$65 \times 10^{-3}$
$89 \times 10^{-3}$

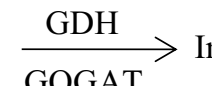
GOGAT
$1.73 \times 10^{-3}$
$4.69 \times 10^{-3}$
Succinyl coenzyme A

Extracellular L-glutamic acid

$\gamma$-PGA

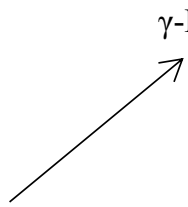

\section{$\gamma-\mathrm{PGA}$}
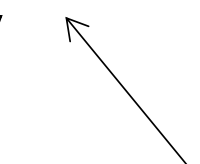

GLR

$\rightarrow$ D-glutamic acid

- 0.44

0.53

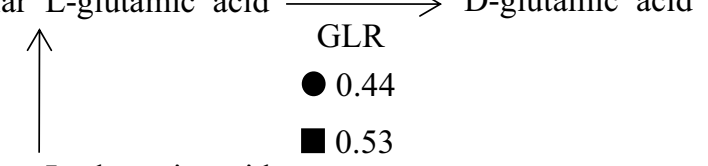

d Isocitric acid

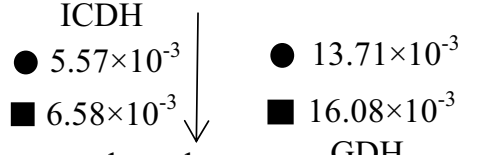

a-ketoglutarate $\mathrm{GDH} \longrightarrow$ Intracellular L-glutamic acid $\longrightarrow$ D-glutamic acid

\begin{tabular}{c|c} 
ODHC & GOGAT \\
$0.76 \times 10^{-3}$ & $\bullet 3.20 \times 10^{-3}$ \\
$0.79 \times 10^{-3}$ & $\square$ \\
Q $3.61 \times 10^{-3}$ \\
Succinyl coenzyme A
\end{tabular}

Succinyl coenzyme A

Extracellular L-glutamic acid

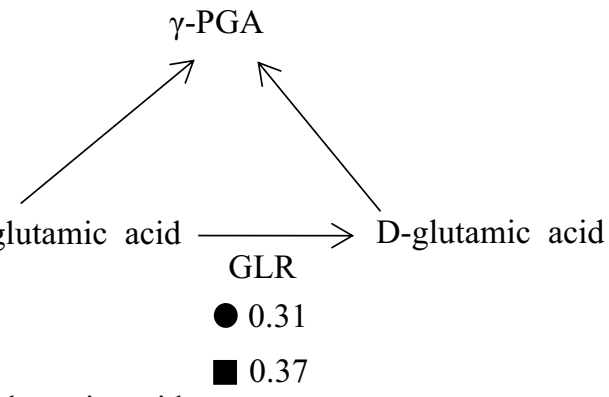

Fig. 5 Enzyme activities in B. siamensis SB1001 and B. siamensis IR10 with a sucrose, $\mathbf{b}$ glucose, $\mathbf{c}$ fructose and $\mathbf{d}$ molasses as the carbon source

fed-batch fermentation. Furthermore, a high average $\gamma$-PGA productivity of $1.85 \mathrm{~g} / \mathrm{L} / \mathrm{h}$ was achieved, which exhibited long-term stability in repeated fed-batch fermentation. B. siamensis IR10 showed great advantages in producing $\gamma$-PGA from different carbon sources, caused by the increased activity of ICDH and GDH and 
the decreased activity of ODHC. This study showed that B. siamensis IR10 is a potential $\gamma$-PGA producer at an industrial scale using a low-cost medium.

\author{
Abbreviations \\ Y-PGA: Poly- $\gamma$-glutamic acid; B. siamensis: Bacillus siamensis; ICDH: Isocitrate \\ dehydrogenase; GDH: Glutamate dehydrogenase; ODHC: a-Oxoglutarate \\ dehydrogenase complex; GOGAT: Glutamate a-oxoglutarate aminotransferase; \\ GLR: Glutamate racemase; HPLC: High-performance liquid chromatography; \\ GPC: Gel permeation chromatogram; RID: Refractive index detector.
}

\section{Acknowledgements}

Not applicable.

\section{Authors' contributions}

DW performed the experiments. DW and $\mathrm{M}-\mathrm{HJ}$ designed the experiments, analyzed the data and drafted the manuscript. HK, SL, D-HK and M-HJ designed and guided the study, editing of manuscript. All authors read and approved the final manuscript.

\section{Funding}

This project was supported by the Nuclear R\&D Program of the Ministry of Science and ICT (MSIT), Republic of Korea.

\section{Availability of data and materials}

All data generated or analyzed during this study are included in this article.

\section{Ethics approval and consent to participate}

Not applicable.

\section{Consent for publication}

Not applicable.

\section{Competing interests}

The authors declare that they have no competing interests.

\section{Author details}

${ }^{1}$ Radiation Utilization and Facilities Management Division, Korea Atomic Energy Research Institute, 29 Geumgu-gil, Jeongeup 56212, Republic of Korea. ${ }^{2}$ Department of Bioactive Material Sciences, Institute for Molecular Biology and Genetics,Center for Fungal Pathogenesis, Jeonbuk National University, Jeonju 54896, Republic of Korea. ${ }^{3}$ Bacteria Research Team, Nakdonggang National Institute of Biological Resources (NNIBR), Sangju 37242, Republic of Korea. ${ }^{4}$ Radiation Research Division, Korea Atomic Energy Research Institute, 29 Geumgu-gil, Jeongeup 56212, Republic of Korea. ${ }^{5}$ Department of Radiation Science and Technology, University of Science and Technology, Daejeon 34113, Republic of Korea.

Received: 8 March 2020 Accepted: 30 April 2020

Published online: 12 May 2020

\section{References}

1. Shih IL, Van YT. The production of poly-( $\gamma$-glutamic acid) from microorganisms and its various ap-plications. Bioresour Technol. 2001;79:207-25.

2. Park SB, Fujimoto T, Mizohata E, Inoue T, Sung MH, Uyama H. Fabrication of poly (gamma-glutamic acid) monolith by thermally induced phase separation and its application. J Microbiol Biotechnol. 2013;23:942-52.

3. Inbaraj BS, Chen BH. Dye adsorption characteristics of magnetite nanoparticles coated with a biopolymer poly( $\gamma$-glutamic acid). Bioresour Technol. 2011;102:8868-76.

4. Taniguchi M, Kato K, Shimauchi A, Xu P, Fujita Kl, Tanaka T, Tarui Y, Hirasawa E. Physicochemical properties of cross-linked poly- $\gamma$-glutamic acid and its flocculating activity against kaolin suspension. J Biosci Bioeng. 2005;99:130-5

5. Shyu Y, Sung W. Improving the emulsion stability of sponge cake by the addition of $\gamma$-polyglutamic acid. J Mar Sci Technol. 2010;18:895-900.
6. Ben-Zur N, Goldman DM. y-Poly glutamic acid: a novel peptide for skin care. Cosmetics Toiletries. 2007;122:65-74.

7. Ye H, Jin L, Hu R, Yi Z, Li J, Wu Y, Xi X, Wu Z. Poly(gamma, L-glutamic acid)cisplatin conjugate effectively inhibits human breast tumor xenografted in nude mice. Biomaterials. 2006;27:5958-65.

8. Inbaraj BS, Wang JS, Lu JF, Siao FT, Chen BH. Adsorption of toxic mercury (II) by an extracellular biopoly-mer poly(gamma-glutamic acid). Bioresour Technol. 2009;100:200-7.

9. $X u Z$ Z, Wan $C, X u X$, Feng $X, X u H$. Effect of poly ( $Y$-glutamic acid) on wheat productivity, nitrogen use efficiency and soil microbes. J Soil Sci Plant Nutr. 2013;13:744-55.

10. Bajaj IB, Lele SS, Singhal RS. A statistical approach to optimization of fermentative production of poly (gamma-glutamic acid) from Bacillus licheniformis NCIM 2324. Bioresour Technol. 2009;100:826-32.

11. Du GG, Yang G, Qu YB, Chen J, Lun SY. Effects of glycerol on the production of poly $(\gamma$-glutamic acid) by Bacillus licheniformis. Process Biochem. 2005;40:2143-7.

12. Feng J, Gu YY, Quan YF, Gao WX, Dang YL, Cao MF, Lu XY, Wang Y, Song CJ, Wang SF. Construction of energy-conserving sucrose utilization pathways for improving poly-gamma-glutamic acid production in Bacillus amyloliquefaciens. Microb Cell Fact. 2017;16:98.

13. Peng YY, Jiang B, Zhang T, Mu WM, Miao M, Hua YF. High-level production of poly $(\gamma$-glutamic acid) by a newly isolated glutamate-independent strain. Bacillus methylotrophicus. Process Biochem. 2015;50:329-35.

14. Shimizu K, Nakamura H, Ashiuchi M. Salt-inducible bionylon polymer from Bacillus megaterium. Appl Environ Microbiol. 2007;73:2378-9.

15. Jeong JH, Kim JN, Wee YJ, Ryu HW. The statistically optimized production of poly(Y-glutamic acid) by batch fermentation of a newly isolated Bacillus subtilis RKY3. Bioresour Technol. 2010;101:4533-9.

16. Zeng W, Chen GG, Wang QL, Zheng SF, Shu L, Liang Q. Metabolic studies of temperature control strategy on poly (gamma-glutamic acid) production in a thermophilic strain Bacillus subtilis GXA-28. Bioresour Technol. 2014;155:104-10

17. Jiang F, Qi GF, Ji ZX, Zhang S, Liu J, Ma X, Chen SW. Expression of glr gene encoding glutamate racemase in Bacillus licheniformis WX-02 and its regulatory effects on synthesis of poly-gamma-glutamic acid. Biotechnol Lett. 2011;33:1837-40.

18. Cai DB, He PH, Lu XC, Zhu CJ, Zhu J, Zhan YY, Wang Q, Wen ZY, Chen SW. A novel approach to improve poly-gamma-glutamic acid production by NADPH regeneration in Bacillus licheniformis WX-02. Sci Rep. 2017;7:43404

19. Zhang W, Gao WX, Feng J, Zhang C, He YL, Cao MF, Li Q, Sun Y, Yang C, Song CJ, Wang SF. A markerless gene replacement method for $B$. amyloliquefaciens LL3 and its use in genome reduction and improvement of poly- $\gamma$-glutamic acid production. App Microbiol Biotechnol. 2014:98:8963-73.

20. Zhang D, Feng XH, Zhou Z, Zhang Y, Xu H. Economical production of poly(gamma-glutamic acid) using untreated cane molasses and monosodium glutamate waste liquor by Bacillus subtilis NX-2. Bioresour Technol. 2012;114:583-8.

21. Tang B, Lei $P, X u Z Q$, Jiang $Y X, X u Z$, Liang JF, Feng XH, Xu H. Highly efficient rice straw utilization for poly-( $\gamma$-glutamic acid) production by Bacillus subtilis NX-2. Bioresour Technol. 2015;193:370-6.

22. Zhu F, Cai J, Zheng Q, Zhu XC, Cen PL, Xu ZN. A novel approach for poly$\gamma$-glutamic acid production using xylose and corncob fibres hydrolysate in Bacillus subtillis HB-1. J Chem Technol Biotechnol. 2014;89:616-22.

23. Wang DX, Hwang JS, Kim DH, Lee SB, Kim DH, Joe MH. A newly isolated Bacillus siamensis SB1001 for mass production of poly- $\gamma$-glutamic acid. Process Biochem. 2020;92:164-73.

24. Meers JL, Tempest DW, Brown CM. 'Glutamine(amide): 2-oxoglutarate amino transferase oxido-reductase (NADP)', an enzyme involved in the synthesis of glutamate by some bacteria. J Gen Microbiol. 1970;64:187-94.

25. Bradford MM. A rapid and sensitive method for the quantitation of microgram quantities of protein utilizing the principle of protein-dye binding. Anal Biochem. 1976;72:248-54.

26. Min J, Lee CW, Gu MB. Gamma-radiation dose-rate effects on DNA damage and toxicity in bacterial cells. Radiat Environ Biophys. 2003;42:189-92.

27. Cao MF, Geng WT, Liu L, Song CJ, Xie H, Guo WB, Jin YH, Wang SF. Glutamic acid independent production of poly- $\gamma$-glutamic acid by Bacillus 
amyloliquefaciens LL3 and cloning of pgsBCA genes. Bioresour Technol. 2011;102:4251-7.

28. Su YS, Li X, Liu QZ, Hou ZW, Zhu XQ, Guo XP, Ling PX. Improved poly- $\gamma$-glutamic acid production by chromosomal integration of the Vitreoscilla hemoglobin gene ( $v g b$ ) in Bacillus subtilis. Bioresour Technol. 2010;101:4733-6.

29. Warda AK, Siezen IJ, Boekhorst J, Wells-Bennik MHJ, Jong A, Kuipers OP, Groot MNN, Abee T. Linking Bacillus cereus genotypes and carbohydrate utilization capacity. PLoS ONE. 2016;11(6):e0156796.

30. Wiesmann C, Beste J, Hengstenberg W, Schulz GE. The three-dimensional structure of 6-phospho- $\beta$-galactosidase from Lactococcus lactis. Structure. 1995;3:961-8.

31. Krispin O, Allmansberger A. The Bacillus subtilis galE gene is essential in the presence of glucose and galactose. J Bacteriol. 1998;180:2265-70.

32. Holden HM, Rayment I, Thoden JB. Structure and function of enzymes of the Leloir pathway for galactose metabolism. Jour Biol Chem. 2003;278:43885-8.

33. Sun TQ, Altenbuchner J. Characterization of a mannose utilization system in Bacillus subtilis. Jour Bacteriol. 2010;192:2128-39.

34. Yu WC, Che Z, Ye H, Liu PZ, Li ZP, Wang YP, Li QB, Yan S, Zhong CJ, He N. Effect of glucose on poly-y-glutamic acid metabolism in Bacillus licheniformis. Microb Cell Fact. 2017;16:22.

35. Bogaard CVD, Kleerebezem M, Kuipers OP, de Vos WM. Control of lactose transport, $\beta$-galactosidase activity, and glycolysis by CcpA in Streptococcus thermophilus: evidence for carbon catabolite repression by a nonphosphoenolpyruvate-dependent phosphotransferase system sugar. Jour Bacteriol. 2000;182:5982-9.

36. Moreno MS, Schneider BL, Maile RR, Weyler W, Saier MH. Catabolite repression mediated by the CcpA protein in Bacillus subtilis: novel modes of regulation revealed by whole-genome analyses. Mol Microbiol. 2004:39:1366-81.

37. Xia J, Xu ZX, Xu H, Liang JF, Li S, Feng XH. Economical production of poly(E-L-lysine) and poly(L-diaminopropionic acid) using cane molasses and hydrolysate of streptomyces cells by Streptomyces albulus PD-1. Bioresour Technol. 2014;164:241-7.

38. Zhang XL, Jantama K, Moore JC, Jarboe LR, Shanmugam KT, Ingrama LO. Metabolic evolution of energy-conserving pathways for succinate production in Escherichia coli. Proc Natl Acad Sci USA. 2009;106:20180-5.

39. Yao J, Xu H, Shi NN, Cao X, Feng XH, Li S, Ouyang PK. Analysis of carbon metabolism and improvement of $\gamma$-polyglutamic acid production from Bacillus subtilis NX-2. Appl Biochem Biotechnol. 2010;160:2332-41.
40. Xu ZQ, Feng XH, Zhang D, Tang B, Lei P, Liang JF, Xu H. Enhanced poly(Yglutamic acid) fermentation by Bacillus subtilis NX-2 immobilized in an aerobic plant fibrous-bed bioreactor. Bioresour Technol. 2014;155:8-14.

41. Kongklom N, Luo HZ, Shi ZP, Pechyen C, Chisti Y, Sirisansaneeyakul S. Production of poly-y-glutamic acid by glutamic acid-independent Bacillus licheniformis TISTR 1010 using different feeding strategies. Biochem Eng J. 2015:100:67-75.

42. de Cesaro A, da Silva SB, Ayub MAZ. Effects of metabolic pathway precursors and polydimethylsiloxane (PDMS) on poly-(gamma)-glutamic acid production by Bacillus subtilis BL53. J Ind Microbiol Biotechnol. 2014;41:1375-82.

43. Jiang YX, Tang B, Xu ZQ, Liu K, Xu Z, Feng XH, Xu H. Improvement of poly$Y$-glutamic acid biosynthesis in a moving bed biofilm reactor by Bacillus subtilis NX-2. Bioresour Technol. 2016;218:360-6.

44. Zeng W, Liang ZQ, Li Z, Bian YX, Li ZH, Tang Z, Chen GG. Regulation of poly-ץ-glutamic acid production in Bacillus subtilis GXA-28 by potassium. J Taiwan Inst Chem E. 2016;61:83-9.

45. Shimizu H, Tanaka H, Nakato M, Nagahisa K, Kimura E, Shioya S. Effects of the changes in enzyme activities on metabolic flux redistribution around the 2-oxoglutarate branch in glutamate production by Corynebacterium glutamicum. Bioproc Biosyst Eng. 2003;25:291-8.

46. Fujita Y. Carbon catabolite control of the metabolic network in Bacillus subtilis. Biosci Biotechnol Biochem. 2009;73:245-59.

47. Mitsunaga H, Meissner L, Palmen T, Bamba T, Büchs J, Fukusaki E. Metabolome analysis reveals the effect of carbon catabolite control on the poly(Y-glutamic acid) biosynthesis of bacillus licheniformis ATCC 9945. J Biosci Bioeng. 2016;121:413-9.

48. Rühl M, Coq DL, Aymerich S, Sauer U. ${ }^{13} \mathrm{C}$-flux analysis reveals NADPHbalancing transhydrogenation cycles in stationary phase of nitrogenstarving Bacillus subtilis. J Biol Chem. 2012;287:27959-70.

49. Kumar R, Pal P. Fermentative production of poly ( $Y$-glutamic acid) from renewable carbon source and downstream purification through a continuous membrane-integrated hybrid process. Bioresour Technol. 2015;177:141-8.

50. Zhao CF, Zhang YW, Wei XT, Hu ZB, Zhu FY, Xu L, Luo MF, Liu HZ. Production of ultra-high molecular weight poly- $\gamma$-glutamic acid with Bacillus licheniformis P-104 and characterization of its flocculation properties. App Biochem Biotechnol. 2013:170:562-72.

\section{Publisher's Note}

Springer Nature remains neutral with regard to jurisdictional claims in published maps and institutional affiliations.
Ready to submit your research? Choose BMC and benefit from:

- fast, convenient online submission

- thorough peer review by experienced researchers in your field

- rapid publication on acceptance

- support for research data, including large and complex data types

- gold Open Access which fosters wider collaboration and increased citations

- maximum visibility for your research: over $100 \mathrm{M}$ website views per year

At BMC, research is always in progress.

Learn more biomedcentral.com/submissions 